\title{
脳卒中片麻瘏患者の車いす駆動速度に影響を及ぼす要因 Factors affecting the wheelchair velocity in stroke patients
}

\author{
大田尾 浩 ${ }^{1} \quad$ 村田 伸 ${ }^{2}$ 八谷 瑞紀 ${ }^{3)}$ 小野 武也 ${ }^{11}$ \\ 中尾 瞳1) 溝上 昭宏() 溝田 勝彦 ${ }^{3)}$ 川上 照彦 \\ Hiroshi OtaO'1), Shin Murata2), Mizuki Hachiya ${ }^{3)}$

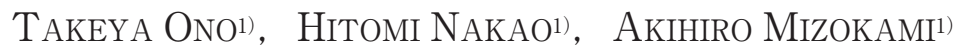 \\ Katsuhiko Mizota ${ }^{3)}$, TerUhiko KawaKami ${ }^{5)}$
}

\begin{abstract}
要旨：[目的］本研究は, 脳卒中片麻疩患者の車いす駆動速度に影響を及ほす要因につい て検討した。[対象］脳卒中片麻痺患者58名とした。［方法］測定項目は, 車いす駆動速度, Br.stage, 握力, 腹筋筋力, 腸腰筋筋力, 下肢筋力, 足指筋力, 座位での下肢荷重力, 座 位バランス，立位バランス，半側空間無視，足底感覚とした。車い寸駆動速度に影響を及 ぼす要因を抽出するために，ステップワイズ法による重回帰分析にて検討した。[結果］ 車いす駆動速度に影響する因子として選択されたのは，腹筋筋力と立位バランスであった。 [結語］脳卒中片麻疩患者の車いす駆動速度には, 腹筋筋力と立位バランスが重要である 可能性が示された。
\end{abstract}

キーワード：車いす駆動速度, 腹筋筋力, 立位バランス, 脳卒中片麻痺患者

\begin{abstract}
Purpose] This study examined factors affecting the wheelchair velocity in stroke patients. [Subjects] Subjects were 58 stroke patients. [Methods] Measurement items included the wheelchair velocity, Br stage, grip strength, abdominal, lower-limb, and toe muscles, lower limb loading force in a sitting position, sitting and standing balance, hemispatial neglect, and plantar perception. To extract factors affecting the wheelchair velocity, a stepwise multiple regression analysis was performed. [Results] The abdominal muscle and standing balance were selected as factors affecting the wheelchair velocity. [Conclusion] The results indicate that the abdominal muscle and standing balance are important for the wheelchair velocity in stroke patients.
\end{abstract}

Keywords: Wheelchair velocity, abdominal muscle, standing balance, stroke patients

受付日：2012年 8 月29日, 採択日：2012年 9 月30日

1) 県立広島大学保健福祉学部

広島県三原市学園町 1 - 1

Tel : 0848-60-1120

Faculty of Health and Welfare, Prefectural University of Hiroshima 1-1 Gakuen-machi, Mihara-shi, Hiroshima, 723-0053, Japan.

2) 京都橘大学健康科学部

Faculty of Health Sciences, Kyoto Tachibana University

3) 西九州大学リハビリテーション学部

Faculty of Rehabilitation Sciences, Nishikyushu University

4) 河畔病院リハビリテーション部

Department of Rehabilitation, Kahan Hospital

5) 吉備国際大学大学院保健科学研究科

Graduate School of Health Science, Kibi International University 


\section{I . はじめに}

脳卒中片麻痺患者の $31 \%$ \% $72 \%$ は，車いすを使用す ることが知られており ${ }^{1-3)}$, 脳卒中片麻痺患者が車い すを使用する割合は高いことが伺える。たとえ歩行能 力を獲得したとしても, 脳卒中発症からの時間経過と ともに歩行能力は低下しやすい")。このように, 脳卒 中片麻痺患者には常に移動能力の低下を引き起こす危 険が伴っており，移動能力の代替手段としての車いす の必要性は高い5)。

車いす駆動能力に関する先行研究では，脳卒中発症 から 3 週間経過した時点で，車いす駆動が自立してい ないと歩行能力の獲得は難しいとされている ${ }^{6)}$ 。また, 車いすの片手片足駆動の難しさは，駆動方法によるも のではなく, 神経学的後遺症に起因するとされており ${ }^{7}$, 車いす駆動能力の阻害因子は麻痺に加えて半側空間無 視や知覚障害などが指摘されている ${ }^{8-10)}$ 。その他に, 入院時に歩行が困難で FIM (functional independence measure）が80点未満, 左片麻痺であると, 退院時に は車いすが必要となる可能性が高いことが明らかにさ れている11)。

一方, 施設入所者の車いすでの自由な移動の可否に は車いす駆動速度が影響することが報告されている ${ }^{12)}$ 。 また，車いす駆動速度は，握力と座位の耐久性と関連 があることが明らかにされている。しかしながら，脳 卒中片麻痺患者の車いす駆動速度に必要な要因は, 十 分に明らかにされていない。また, 脳卒中片麻痺患者 の車椅子駆動速度に影響を及ぼす要因を知ることは, 車椅子駆動の指導においても有用であると考える。本 研究の目的は, 脳卒中片麻痺患者を対象に車いす駆動 速度に影響を及ぼす要因を明らかにすることである。

\section{II. 対象と方法}

\section{1. 対 象}

対象は，入院中もしくは通院中の脳卒中片麻痺患者 58 名（平均年齢 $66 \pm 16$ 歳）とした。そのうち，右片麻 痺は24名, 左片麻痺は34名であった。発症から平均 20.5 土39力月経過していた（表 1 ）。対象の取り込み基準 は, 初発の脳卒中であること, 自力で座位保持が可能 なこと, 研究の参加に同意が得られることとし, 以下 の評価項目を測定できた者を対象とした。歩行練習中 で車いすを併用している者も対象に含めた。対象の除 外基準は, 重度な失語症, 両麻痺, 脳卒中に起因しな い片麻痺とした。

研究の趣旨と内容について被検者本人もしくはその
表 1 . 対象の属性 $(\mathrm{n}=58)$

\begin{tabular}{llc}
\hline 年齢 $($ 歳 & & $66.4 \pm 15.7$ \\
性別 & 男性 & 39 \\
& 女性 & 19 \\
麻疩側 & 右片麻疩 & 24 \\
& 左片麻痺 & 34 \\
病日数 $(\text { 月 })^{\dagger}$ & & $2.8(1-133)$ \\
疾患名 & 脳梗塞 & 29 \\
& 脳出血 & 24 \\
& くも膜下出血 & 5 \\
身長 $(\mathrm{cm})$ & & $158.6 \pm 12.0$ \\
体重 $(\mathrm{kg})$ & & $56.6 \pm 13.6$ \\
$\mathrm{BMI}\left(\mathrm{kg} / \mathrm{cm}^{2}\right)$ & & $22.5 \pm 4.5$ \\
$\mathrm{FIM}-\mathrm{M}($ 点 $)$ & & $64.2 \pm 22.9$ \\
\hline
\end{tabular}

Mean \pm SD, $\uparrow:$ Median (range)

家族に文書と口頭で十分に説明し，理解を得た上で協 力を求めた。また，研究の参加は自由意思であること， 参加しない場合に不利益がないことを説明した。本研 究は，調査を行った施設の施設長および現場長の承認 を事前に得てから実施した。なお，本研究は県立広島 大学研究倫理委員会の承認を受けている（第 $12 \mathrm{MH} 011$ 号)。

\section{2. 方 法}

測定項目は，車いす駆動速度, Br.stage(Brunnstrom recovery stage), 握力, 腹筋筋力, 腸腰筋筋力, 大 腿四頭筋筋力，足指筋力，座位での下肢荷重力，座位 バランス, 立位バランス, 半側空間無視, 麻痺側足底 感覚とした。

車いす駆動速度は, 幅 $2 \mathrm{~m}$, 直線 $10 \mathrm{~m}$ の車いす駆動 速度をストップウォッチにて計測した。計測はフフッ トレストが開始線を越えてから $10 \mathrm{~m}$ 先の線を越えるま での時間を測定した。被検者には，できるだけ速く駆 動するよう指示をした。その際，駆動方法は問わず， 左右にそれた者に対しては介助をせずに自力で修正を させた。修正が困難で，所要時間が 120 秒以上を超過 した者は車いす駆動に介助を要すると判断し，本研究 の対象から除外した。

腹筋筋力の計測は, Bohannon ら ${ }^{13)}$ の方法に準じて 実施した。HHD (hand held dynamometer)（アニマ 社製，等尺性筋力測定装置 $\mu$ Tas F-1）を用いて測 定した。被検者に端座位をとらせ，両上肢は体幹の前 で組ませ，被検者の両大腿をもう一人の検者が固定し た。胸骨部にセンサーパッドをあてて検者が後方に押 した。被検者には後方に倒れないように端座位姿勢を 保持するように指示をした。測定時に，被検者が後方 
へ倒れないように注意した。計測は 2 回行い, 最大値 を体重比百分率（\%）に換算し腹筋筋力とした。

腸腰筋筋力の測定は, 左右の腸腰筋の最大等尺性収 縮筋力により評価した。被検者には端座位をとらせ, HHD のセンサーパッドは, 被検者の大腿遠位上部に あて, ベルトを検者の足底で踏みこみ固定した。その 後, 最大努力による等尺性股関節屈曲運動を行わせた。 非麻盘側と麻痺側を 2 回ずつ計測し, それぞれ最大值 を体重比百分率（\%）に換算し非麻痺側等尺性腸腰筋 筋力, 麻疩側等尺性腸腰筋筋力とした。

下肢筋力は, 左右の大腿四頭筋の最大等尺性収縮筋 力により評価した。測定には，HHDを用いた。被検 者に端座位をとらせ，膝関節90度屈曲位とした。HHD のセンサーパッドは, ベルトを用いてプラットホーム の二本の支柱と被検者の下腿遠位部に固定した。その 後, 最大努力による等尺性滕伸展運動を行わせた。測 定時には，殿部がベッドより浮かないように留意した。 測定は, 非麻痺側と麻痺側を左右 2 回ずつ行い, それ ぞれの最大值を体重比百分率に換算し非麻痺側下肢筋 力，麻痺側下肢筋力とした。

足指筋力は, 足指筋力測定器 (竹井機器工業製, $\mathrm{T}$. K.K3360）を用いて測定した。座位にて, 非麻疩側下 肢を筋力測定器に乗せ，踵部を固定した。開始の合図 で足指把持バーをしっかりと把持させた。その際，足 指把持バーを下に押さえつけないこと, 踵部を浮かさ ないことに留意した。測定は 2 回行い, 最大值を体重 比百分率（\%）に換算し，足指筋力とした。

座位での下肢荷重力は, 被検者に膝関節90度屈曲位 の座位をとらせ，非麻痺側の足底に体重計を置いた。 その際，治療台端と膝窝部間を拳 1 個分空けた。測定 開始の合図とともに, 被検者に非麻痺側下肢で体重計 を最大努力下で押させ，その間に安定して示された数 值を計測した。ただし，手で治療台を引かないこと， 殿部が治療台から離れないことに留意した。2 回計測 し，体重比百分率（\%）に換算し座位での下肢荷重力 とした。

座位バランスは, SRT (seated reach test) ${ }^{14)} に よ$ り測定した。端座位は, 股関節と膝関節は90度屈曲位 とし, 足底は床面に接地させた。肩峰と大転子を結ぶ 線が床面と垂直となる位置を開始肢位とした。非麻痷 の肩関節90度屈曲位にて, 手掌面を床面に向け前方へ のリーチ距離を 2 回測定し, 最大值を採用し, 身長で 除した（\%)。

立位バランスは，ファンクショナルリーチ計測機
（OG 技研社製 GB-200）を用いて，FRT（functional reach test）により測定した。被検者を，歩幅を肩幅 程度に開いて立たせた。非麻痺側上肢を前腕回内・肘 関節伸展 - 肩関節 $90^{\circ}$ 屈曲位に保持させ, 指尖の位置 を測定開始肢位とした。測定開始の合図にあわせ，被 検者にできる限り前方にリーチを行わせた。前方へ リーチする際は，被検者に足部を動かさないように注 意をし, 測定開始肢位に戻らせて測定終了とした。リー チ距離は 2 回測定し, 最大值を採用し, 身長で除した (\%)。

足底感覚は，10点法 ${ }^{15}$ にて足底母指球の触覚を評価 した。測定肢位は座位とし, 被検者の足底が床につか ない高さに治療台を設定した。まず，麻痺側の足底を 軽く触れることが判別できるかを確認した後に，左右 同程度の刺激を加え, 非麻瘦側を基準の 10 点としたと きに麻痺側の触覚はどの程度にあるかを評価した。

半側空間無視は, 線分二等分検査にて評価した。A 4 用紙に $200 \mathrm{~mm}$ の直線を左右の位置をずらして平行に 3 本引いた。被検者には，それぞれ中央であると思う 部分に印をつけさせた。その後, 直線の中央からつけ た印までの偏移をmm単位で計測した。

統計処理は, 車いす駆動速度と各測定值との関連を Spearman の順位相関係数による単変量解析にて説明 変数を絞り込んだ。次に, 車いす駆動速度に影響を及 ぼす因子を抽出するために，従属変数を車いす駆動速 度, 独立変数は単変量解析で有意であった項目とし, ステップワイズ法による重回帰分析にて分析した。さ らに, 交絡因子と考えられる年齢, 性別, 麻瘒側, BMI

（body mass index）を強制投入した重回帰分析にて, 車いす駆動速度に影響する要因を抽出した。統計解析 にはPASW Statistics18.0（SPSS Japan）を用い, 有 意水準は 5 \%とした。

\section{III. 結 果}

車いす駆動速度と各測定值との単相関分析の結果, Br.stage 下肢 $(r=-0.44)$, 握力 $(r=-0.58)$, 腹筋 筋力 $(r=-0.49)$, 非麻痺側腸腰筋筋力 $(r=-0.64)$, 麻痺側腸腰筋筋力 $(r=-0.49)$, 非麻痺側下肢筋力 $(r$ $=-0.68)$, 麻痺側下肢筋力 $(r=-0.46)$, 足指筋力 $(\mathrm{r}=-0.62)$, 座位での下肢荷重力 $(r=-0.67)$, 座 位バランス $(r=-0.67)$ ，立位バランス $(r=-0.74)$, 半側空間無視 $(r=-0.39)$, 足底感覚 $(r=-0.33)$ で 有意な相関が認められた（表 2 )。

車いす駆動速度と各測定項目との関連を分析した結 
表 2．車椅子駆動速度と各測定項目との関連

\begin{tabular}{|c|c|c|c|c|c|c|c|c|c|c|c|c|c|c|c|}
\hline & $\begin{array}{c}\text { 車椅子 } \\
\text { 駆動速度 }\end{array}$ & $\begin{array}{c}\text { Br.stage } \\
\text { 上肢 }\end{array}$ & $\begin{array}{c}\text { Br.stage } \\
\text { 手指 }\end{array}$ & $\begin{array}{c}\text { Br.stage } \\
\text { 下肢 }\end{array}$ & 握力 & 腹筋筋力 & $\begin{array}{l}\text { 非麻痺側 } \\
\text { 腸腰筋力 }\end{array}$ & $\begin{array}{c}\text { 麻㾝側 } \\
\text { 腸腰筋力 }\end{array}$ & $\begin{array}{l}\text { 非麻痺側 } \\
\text { 下肢筋力 }\end{array}$ & $\begin{array}{c}\text { 麻瘢側 } \\
\text { 下肢筋力 }\end{array}$ & 足指筋力 & $\begin{array}{c}\text { 座位での } \\
\text { 下肢荷重力 }\end{array}$ & $\begin{array}{c}\text { 座位 } \\
\text { バランス }\end{array}$ & $\begin{array}{c}\text { 立位 } \\
\text { バランス }\end{array}$ & $\begin{array}{c}\text { 半側空間 } \\
\text { 無視 }\end{array}$ \\
\hline Br.stage 上肢 & -0.26 & & & & & & & & & & & & & & \\
\hline Br.stage 手指 & -0.23 & $0.97^{* *}$ & & & & & & & & & & & & & \\
\hline Br.stage 下肢 & $-0.44^{* *}$ & $0.89 * *$ & $0.86^{* *}$ & & & & & & & & & & & & \\
\hline 握力 & $-0.58^{* *}$ & $0.30^{*}$ & $0.30^{*}$ & $0.30^{*}$ & & & & & & & & & & & \\
\hline 腹筋筋力 & $-0.49^{* *}$ & 0.25 & 0.25 & 0.25 & $0.64^{* *}$ & & & & & & & & & & \\
\hline 非麻瘏側腸腰筋力 & $-0.64^{* *}$ & $0.40^{* *}$ & $0.39^{* *}$ & $0.39^{* *}$ & $0.63^{* *}$ & $0.62^{* *}$ & & & & & & & & & \\
\hline 麻痺側腸腰筋力 & $-0.49^{* *}$ & $0.77^{* *}$ & $0.77^{* *}$ & $0.77^{* *}$ & $0.47^{* *}$ & $0.50^{* *}$ & $0.56^{* *}$ & & & & & & & & \\
\hline 非麻瘏側下肢筋力 & $-0.68^{* *}$ & $0.43^{* *}$ & $0.43^{* *}$ & $0.43^{* *}$ & $0.69^{* *}$ & $0.57^{* *}$ & $0.63^{* *}$ & $0.50^{* *}$ & & & & & & & \\
\hline 麻痺側下肢筋力 & $-0.46^{* *}$ & $0.80^{* *}$ & $0.80^{* *}$ & $0.80^{* *}$ & $0.49^{* *}$ & $0.46^{* *}$ & $0.42^{* *}$ & $0.88^{* *}$ & $0.57^{* *}$ & & & & & & \\
\hline 足指筋力 & $-0.62^{* *}$ & $0.29^{*}$ & $0.29^{*}$ & $0.29^{*}$ & $0.67^{* *}$ & $0.52^{* *}$ & $0.60^{* *}$ & $0.39^{* *}$ & $0.56^{* *}$ & $0.45^{* *}$ & & & & & \\
\hline 下肢荷重力 & $-0.67^{* *}$ & $0.45^{* *}$ & $0.45^{* *}$ & $0.45^{* *}$ & $0.69 * *$ & $0.62^{* *}$ & $0.66^{* *}$ & $0.59^{* *}$ & $0.72^{* *}$ & $0.66^{* *}$ & $0.69^{* *}$ & & & & \\
\hline 座位バランス & $-0.67^{* *}$ & 0.20 & 0.20 & 0.20 & $0.45^{* *}$ & $0.35^{* *}$ & $0.40^{* *}$ & 0.25 & $0.46^{* *}$ & 0.28 & $0.51^{* *}$ & $0.47^{* *}$ & & & \\
\hline 立位バランス & $-0.74^{* *}$ & $0.35^{* *}$ & $0.35^{* *}$ & $0.35^{* *}$ & $0.61^{* *}$ & $0.40^{* *}$ & $0.63^{* *}$ & $0.43^{* *}$ & $0.69^{* *}$ & $0.38^{* *}$ & $0.57^{* *}$ & $0.55^{* *}$ & $0.60^{* *}$ & & \\
\hline 半側空間無視 & $-0.39^{*}$ & 0.03 & 0.03 & 0.03 & 0.04 & 0.08 & 0.21 & 0.07 & 0.21 & 0.16 & 0.25 & 0.14 & $0.45^{* *}$ & $0.31^{*}$ & \\
\hline 足底感覚 & $-0.33^{*}$ & $0.57^{* *}$ & $0.57^{* *}$ & $0.57^{* *}$ & 0.24 & 0.19 & 0.20 & $0.54^{* *}$ & 0.25 & $0.58 * *$ & 0.04 & 0.21 & 0.29 & 0.17 & 0.20 \\
\hline
\end{tabular}

${ }^{*} \mathrm{p}<0.05, \quad{ }^{* *} \mathrm{p}<0.01, \quad$ Spearaman の順位相関係数

表 3. 車椅子駆動速度を従属变数とする重回帰分析

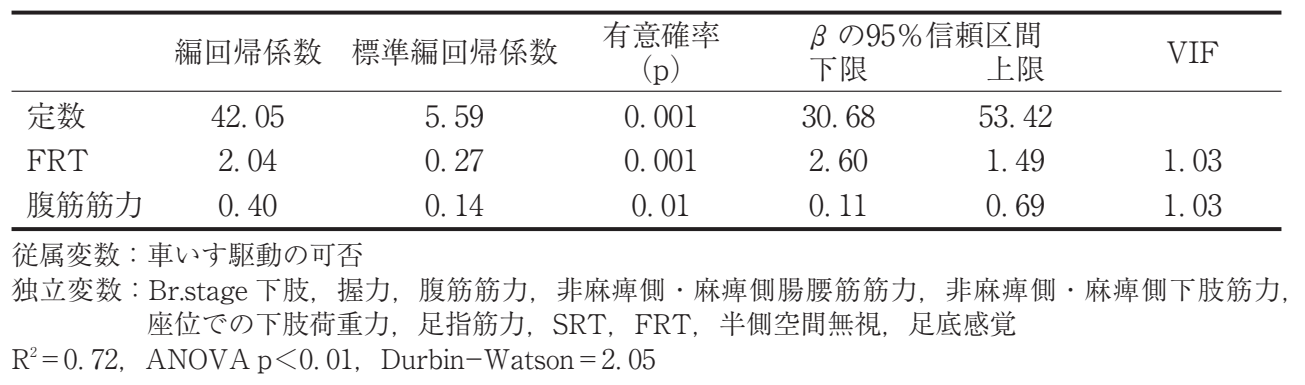

果から, 重回帰分析の従属变数を車いす駆動速度とし, 独立変数は下肢の Br.stage, 握力, 腹筋筋力, 非麻瘏 側 - 麻瘏側腸腰筋筋力, 非麻疩側 - 麻瘏側下肢筋力, 座位での下肢荷重力, 足指筋力, 座位バランス, 立位 バランス, 半側空間無視および足底感覚とした。重回 㛿分析の結果, 選択された要因は, 立位バランス ( $<0.01)$, 腹筋筋力 $(\mathrm{p}<0.01)$, 非麻痺側腸腰筋筋力 （p<0.01）であった。交絡因子を調整するために, 選択された立位バランス, 腹筋筋力, 非麻瘏側腸腰筋 筋力に加えて, 年齢, 性別, 麻痺側, BMI を強制投 入した重回帰分析を行った。その結果, 車いす駆動速 度と非麻瘏側腸腰筋筋力との有意性が保たれなかった。 最終的に選択された車いす駆動速度に影響を及ぼす要 因は，腹筋筋力 $(\mathrm{p}<0.01)$ と立位バランス $(\mathrm{p}<0.01)$ であった（表 3$) 。$

\section{IV. 考 察}

車いす駆動において，ハンドリムを前下方に押す推 進相では，体幹を前傾し，重心を前方とへ移動する ${ }^{16)}$ この重心移動は, ハンドリムを駆動する際の肩関節屈 筋の筋力と肩関節屈曲速度を助ける働きがある ${ }^{17}$ 。ま
た，体幹を前傾することにより，ハンドリムを長く駆 動することが可能となり，効率よくハンドリムを押す 力を伝達することができる18)。ところが，体幹前傾の 程度は腹筋筋力の強さと反比例するとされている ${ }^{18)}$ 。 つまり, 腹筋筋力が強いほど, 体幹は前傾しなくとも 車いすの推進力を得ることが可能となる。これは, 腹 筋群などの体幹筋の活動により脊柱の剛性を高めるこ とで, 車いす推進中の体幹の安定性を確保するとされ ている ${ }^{19)}$ 。より速い推進力, より強い推進力を得るた めには腹筋群の活動が求められる ${ }^{16)}$ 。

今回, 座位バランスはSRTにて, 立位バランスは FRTにて評価を行った。これらのリーチテストは, 体幹機能障害の程度とバランス能力を反映することが 確認されている ${ }^{20)}$ 。しかし, 車いす駆動速度と座位バ ランスとの間には有意な関係は認められず，立位バラ ンスが選択された。このことから，車いす駆動速度に は座位バランスよりも立位バランスのような高度な姿 勢制御能力が要求されている可能性がある。脳卒中片 麻痺患者の体幹筋力やバランス能力は, 上下肢機能と 比較して著しく損なわれることが指摘されている ${ }^{21}$ 。 さらに, 脳卒中患者の体幹屈曲の筋力低下は, バラン 
ス能力に影響し, 歩行能力や移乗能力と関連が認めら

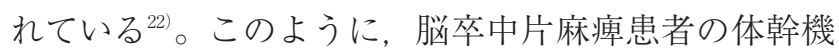
能とバランス能力は密接に関わりあっており, 脳卒中 片麻疩患者の車いす駆動速度に影響を及ぼす要因とし て腹筋筋力と立位バランスが選択されたのは, 妥当な 結果と考える。

以上のように，脳卒中片麻痹患者における車いす駆 動速度に影響を及ぼす要因は，立位バランスと腹筋筋 力であること, 車いす駆動速度と, 麻疩の程度, 握力, 座位バランス，および下肢筋力との間には有意な関係 は認められなかったことから, 脳卒中片麻痺患者が車 いす駆動速度を向上するためには，とくに立位バラン スと腹筋筋力へのアプローチが重要であることが示唆 された。ただし今回は, 車いす操作を含めた検討は行っ ておらず，上肢筋力として評価したのは握力のみで あった。今後はこれらを含めた車いす駆動能力の縦断 研究拉よび介入による効果の検証が必要である。本研 究の結果は, 脳卒中片麻痺患者における車いす駆動の 指導において一助となるであろう。

\section{引用文献}

1) Lipson DM, Sangha H, Foley NC, et al: Recovery from stroke: differences between subtypes. Int J Rehabil Res, 2005, 28(4): 303-308.

2 ) Teasell RW, Foley NC, Bhogal SK, et al.: A rehabilitation program for patients recovering from severe stroke. Can J Neurol Sci, 2005, 32(4): 512-517.

3 ) Mountain AD, Kirby RL, MacLeod DA, et al.: Rates and predictors of manual and powered wheelchair use for persons with stroke: a retrospective study in a Canadian rehabilitation center. Arch Phys Med Rehabil, 2010, 9(4): 639-643.

4 ) Garber SL, Bunzel R, Monga TN.: Wheelchair utilization and satisfaction following cerebral vascular accident. J Rehabil Res Dev, 2002, 39(4): 521-534.

5 ) Gresham GE, Granger CV, Linn RT, et al.: Status of functional outcomes for stroke survivors. Phys Med Rehabil Clin N Am, 1999, 10(4): 957-666.

6 ) Blower PW, Carter LC, Sulch DA.: Relationship between wheelchair propulsion and independent walking in hemiplegic stroke. Stroke, 1995, 26(4): 606-608.

7 ) Kirby RL, Adams CD, MacPhee AH, et al:: Weelchair-skill performance: controlled comparison between people with hemiplegia and able-bodied people simulating hemiplegia. Arch Phys Med Rehabil, 2005, 86(3): 387-393.

8 ) Cherney LR, Halper AS, Kwasnica CM, et al: Recovery of functional status after right hemisphere stroke: relationship with unilateral neglect. Arch Phys Med Rehabil, 2001, 82(3): 322-328.

9 ) Eskes GA, Butler B, McDonald A, et al: Limb activation effects in hemispatial neglect. Arch Phys Med Rehabil, 2003,
84(3): 323-328.

10) Azouvi P, Olivier S, de Montety G, et al:: Behavioral assessment of unilateral neglect: study of the psychometric properties of the Catherine Bergego Scale. Arch Phys Med Rehabil, 2003, 84(1): 51-57.

11) Mountain AD, Kirby RL, MacLeod DA, et al.: Rates and predictors of manual and powered wheelchair use for persons with stroke: a retrospective study in a Canadian rehabilitation center. Arch Phys Med Rehabil, 2010, 9(4): 639-643.

12) Simmons SF, Schnelle JF, MacRae PG, et al: Wheelchairs as mobility restraints: predictors of wheelchair activity in nonambulatory nursing home residents. J Am Geriatr Soc, 1995, 43(4): 384-388.

13) Bohannon RW, Cassidy D, Walsh S.: Trunk muscle strength is impaired multidirectionally after stroke. Clin Rehabil, 1995, 9(1): 47-51.

14) Field-Fote EC, Ray SS.: Seated reach distance and trunk excursion accurately reflect dynamic postural control in individuals with motor-incomplete spinal cord injury. Spinal Cord, 2010, 48(10): 745-749.

15) Strauch B, Lang A, Ferder M,et al.: The ten test. Plast Reconstr Surg, 1997, 99(4): 1074-1078.

16) Yang YS, Koontz AM, Triolo RJ, et al: Surface electromyography activity of trunk muscles during wheelchair propulsion. Clin Biomech, 2006, 21(10): 1032-1041.

17) Guo LY, Su FC, Wu HW, et al.: Mechanical energy and power flow of the upper extremity in manual wheelchair propulsion. Clin Biomech, 2003, 18(2): 106-1014.

18) Sanderson DJ, Sommer HJ 3rd.: Kinematic features of wheelchair propulsion. J Biomech, 1985, 18(6): 423-429.

19) Howarth SJ, Polgar JM, Dickerson CR, et al.: Trunk muscle activity during wheelchair ramp ascent and the influence of a geared wheel on the demands of postural control. Arch Phys Med Rehabil, 2010, 91(3): 436-442.

20) Petrofsky JS.: A device for the evaluation of sitting and reach balance in people in wheelchairs and standing. J Med Eng Technol, 2006, 30(6): 358-367.

21) Bohannon RW.: Recovery and correlates of trunk muscle strength after stroke. Int J Rehabil Res, 1995, 18: 162-167.

22) Karatas M, Cetin N, Bayramoglu M, et al: Trunk muscle strength in relation to balance and functional disability in unihemispheric stroke patients. Am J Phys Med Rehabil, 2004, 83(2): 81-87. 